УДК [929: 2-41] (477) «1920/1930»

DOI: https://doi.org/10.33782/eminak2019.3(27).316

\title{
РЕФЛЕКСІЇ МИТРОПОЛИТА В. ЛИПКІВСЬКОГО НА ВИКЛИКИ ПЕРЕД ВІРУЮЧИМИ У РАДЯНСЬКІЙ УКРАЇНІ
}

\author{
Тетяна Савчук \\ Запорізький національний університет (Запоріжжя, Україна) \\ e-mail: savatg@ukr.net \\ ORCID: https://orcid.org/0000-0002-1315-0513
}

У статті висвітленні рефлексії митрополита Української автокефальної православної церкви В. Липківського на виклики перед православними віруючими у 1920-1930-х рр. Проповіді митрополита віддзеркалили уявлення духовенства про життєві перипетії, світоглядні кризи, що постали перед ними та вірянами в умовах суспільних карколомних змін. Митрополит В. Липківський - украӥнський пророк, який передбачив суттєві проблеми людства та християнства у XX - XXI cm. - десакралізацію особистості, безцерковне та побутове православ'я.

Ключові слова: митрополит В. Липківський, проповіді, рефлексії, антицерковна боротьба, радянська влада

Вивчення повсякденного буття тієї чи іншої верстви сприяє реконструкції історичної епохи, збагачує ретроспективну картину минулого. Структури повсякдення доволі широкі. Найбільш складними для дослідження є рефлексії людини як спосіб усвідомлення специфіки свого буття, процес осмислення як побутових, так і загальнолюдських проблем, влади, держави.

Дуже важко зануритися у внутрішній світ людей. Проповіді можуть стати у пригоді важливим історичним джерелом уявлень духовенства про життєві перипетії, світоглядні кризи, що постали перед ними та вірянами, стратегії побудови нового життя в умовах суспільних карколомних змін 1920-1930-х рр.

У представленій статті звернемося до проповідей Василя Липківського (1864$1937)$ - першого предстоятеля Української автокефальної православної церкви (УАПЦ), провідника українського церковного руху та національних ідей1․ 197 проповідей писалися, як літературні твори, у часи, коли митрополит вимушено відійшов від служіння. Однак, ймовірно, що їх основу могли становити нотатки, зроблені під час виголошення промов у храмах.

Через обставини знищення владою української церкви й особливості останніх років життя митрополита гомілетична спадщина збереглася лише за межами України. В архівних документах не виявлено матеріалів гомілетичної спадщини УАПЦ. Усі збірники проповідей складаються з вивезених закордон і надісланих поштою самим митрополитом В. Липківським до о. П. Маєвського 2.

Історик І.Преловська влучно підкреслила, що проповіді владики через наяв-

\footnotetext{
${ }^{1}$ Митрополит Василь Липківський. Проповіді на неділі й свята. Слово Христове до українського народу. URL: http://lypkivskyivasyl.in.ua/propovidi/propovidi.html

2 Преловська І.М. Джерела з історії Української Автокефальної Православної Церкви (1921-1930) Української Православної Церкви (1930-1939) / Наук. ред. А.Л. Зінченко. НАН України. Інститут української археографії та джерелознавства ім. М.С. Грушевськото. Київ: Інститут української археографії та джерелознавства ім. М.С. Грушевськото, 2013. С. 341.
} 
ність у суто церковних текстах актуальної для вірних інформації, була відгуком на тодішні події, є специфічним джерелом про умови життя та діяльності УАПЦ 19201930-х рр. ${ }^{3}$ І це не дивно, оскільки проповідь передбачає екстраполяцію Біблійного вчення на сучасне життя проповідника.

Дослідниця присвятила спеціальну розвідку огляду гомілетичної спадщини В. Липківського ${ }^{4}$. Зокрема, її зацікавило ставлення митрополита УАПЦ до інших церков.

Не можна не погодитися із твердженням літературознавця В. Поліщука, що проповіді митрополита В. Липківського «є не тільки глибокою скарбницею українського духу, але й вельми цінним внеском у розвиток проповідницького жанру»5. Науковець звернув увагу на національні аспекти у проповідях митрополита, проілюстрував тезу про те, що наскрізним образом у промовах проходить образ Тараса Шевченка.

Метою даної публікації $\epsilon$ висвітлення рефлексій владики В. Липківського на виклики, що постали перед вірянами в умовах антицерковної політики радянської влади.

Перед нами рефлексії ерудованої та сміливої людини - знавця історії, філософії, розвитку науки. В. Липківський у проповідях демонструє глибокі знання історії українського народу та церкви.

На всі знакові події у земному житті Ісуса Христа - народження, водохрещення, богоявлення, чудеса, розп'яття, воскресіння - В. Липківський готував проповіді, в яких містився зв'язок з історичним минулим церкви, заклик до оновлення християнського життя, до щирого справжнього сприйняття християнських цінностей. Проповіді пронизані любов’ю до людей, до українських давніх церковних традицій. Вони пропагували християнські доктрини з акцентуванням особливої уваги на перевагах саме Української автокефальної православної церкви. Примітно, що у проповідях В. Липківський посилається на Святе Письмо і зовсім не згадує іншої церковної літератури.

Як відомо, у радянській Україні насаджувалася матеріалістична світоглядна система, яка мала за абсолют матерію та повністю ігнорувала духовний світ, поняття Бога. Ії̈ поширення призводило до руйнування усталених духовних цінностей попередньої епохи, появи есхатологічних настроїв. Владика В. Липківський не міг не відреагувати на спроби комуністів побудувати суспільство винятково із матеріалістів.

В. Липківський з іронією назвав провідників нової влади «новими вчителями», які відкидали Бога, від яких не можна вимагати благости та милосердя. Він пояснював, що це природно, оскільки ніхто не благий, окрім Бога. «Нові вчителі», на його думку, вимагають - «продай вітчизну, продай душу... - от усе»6. В. Липківський пророче застерігав вірян, які відмовлялися відвідувати церкву, відрікалися від Бога, що вони нічого не отримають, окрім кількох червінців і кусня хліба.

\footnotetext{
3 Ibid. C. 340.

4 Преловська І.М. Відображення в гомілетичній спадщині митрополита УАПЦ Василя Липківського його ставлення до інших Церков (до 150-ої річниці (7/19 березня 1864 р. - 27 листопада 1937 р.) з дня народження митрополита УАПЦ Василя Липківського) // Труди Київської Духовної Академії. 2014. № 14. С. 241-251.

5 Поліщук В.Т. Проповіді митрополита Василя Липківського: тяглість традиції й нові акценти жанру // Поліщук В.Т. Вибране. Т. 2. Розстріляні таланти (Репресовані письменники Черкащини). Черкаси: видавець Ю.А. Чабаненко, 2013. 418 с.

6 Шлях до життя дійсний і обманний (Неділя 30-та по Тройці) // Митрополит Василь Липківський. Проповіді на неділі й свята. Слово Христове до українського народу. URL: http://lypkivskyivasyl.in.ua/propovidi/016-shljah.html
} 
Десакралізація життя, на думку митрополита, не тільки руйнувала церковні інституції, а й позбавляла людину відчуття недоторканості, гідності ії особи. Фактично митрополит відчував епоху тоталітаризму, коли відбудеться десакралізація особи, їі перетворення на частину людської біомаси. Із хвилюванням він говорив: «Не дивно, що з цих первотин золото стало тепер справжнім всесвітнім ідеалом, що за нього ведуться великі війни, йде невпинна гризня між народами, витрачаються мільйони людности. А внутрішність, а душа людська, совість людська зовсім знехтувана»7.

В. Липківський засуджував таке явище, як безцерковне православ'я. Вказав на те, що християни тільки називаються, а нічим не відрізняються від «старого поза християнського розуміння Христової віри», як часто християни залишаються «рабами земного царства». Владика закликав - «християни повинні провадити і життя християнське, повинні утворювати в себе дійсну Христову церкву, з себе утворювати нову людину, а з нашого народу новий народ - рабів царства небесного ${ }^{8} .$. Наша Українська Православна Автокефальна Церква і має своїм головним і кінцевим завданням проводити в життя нашого народу чисті заповіти Ісуса Христа - Господа нашого»9.

В. Липківський переймався тим, що не тільки міські мешканці, а й навіть селяни не тримають постів, не відвідують постові молитви, нібито вони лише для дяків і священників. Причину зниження релігійності він вбачав і в тому, що церква перестала бути храмом любові, а $є$ храмом виконання суворих приписів. Він закликав своїх колег, що «церква повинна стати нашою рідною матір'ю і підійти до нас - своїх дітей з любов'ю і чулістю матері, а не з суворістю старовинних монахів»10.

Пошуки протидії десакралізації життя владика вбачав у піднятті особистої віри людини у Бога. Мабуть, частіше за все у його проповідях постає тема збереження віри та протидії атеїзації населення. В. Липківський з іронією говорив про прагнення влади змінити релігійний світогляд: «I тепер вам кажуть: не треба вам Бога, ми вам все зробимо. Раю хочеться? Зробимо земний рай; дощу треба - дамо! Утіх всяких дамо скільки хочете, тільки нас величайте, до нас, як до богів, звертайтеся, а Христа, а Бога забудьте...»11. Владика закликав вірян не забувати, що «нові боги» помруть, як усі люди. I потрібно, як Ісус страждав і усе переміг, вірянам з Ним страждати й отримати вічне життя.

Спростуванню антирелігійних ідей В. Липківський присвятив спеціальну проповідь. Його бентежили антирелігійні тези, на кшталт «всяка віра і зокрема християнство, це зовсім не $\epsilon$ просвіщення; а навпаки затьмарення людини, чи народу, $\epsilon$ опіюм, що присипляє, забиває памороки людині, не дає їй тверезо і ясно подивитись на світ, на життя, є темрява, а навпаки цілковите визволення від віри, безбожництво, безвір-

\footnotetext{
7 Філософія по стихіях світу цього і по Христу (Новий рік - Колос. 2, 8-12) // Митрополит Василь Липківський. Проповіді на неділі й свята. Слово Христове до українського народу. URL: lypkivskyivasyl.in.ua/propovidi/004-phylos.html

8 Ім'я «Ісус», «Христос», «Християни» (Новий рік) // Митрополит Василь Липківський. Проповіді на неділі й свята. Слово Христове до українського народу. URL: lypkivskyivasyl.in.ua/propovidi/001-isus.html.

9 Ibid.

10 Піст, як засіб церковного виховання (Неділя Сиропустна) // Митрополит Василь Липківський. Проповіді на неділі й свята. Слово Христове до українського народу. URL: lypkivskyivasyl.in.ua/propovidi/034-pist.html

${ }_{11}$ Син Божий, що став Чоловіком, і чоловік, що уявить себе Богом (I-ша Пасія) // Митрополит Василь Липківський. Проповіді на неділі й свята. Слово Христове до українського народу. URL: lypkivskyivasyl.in.ua/propovidi/047-syn.html
} 
ство $є$ справжнє просвіщення людства»12. В. Липківський побудував свою систему контраргументів, спираючись на наукові знання: «вся минула історія людства безперечно свідчить - і це свідчення ніякий безвірницький галас не в силі заглушити, що віра завжди була найбільшим двигателем людської освіти, людського поступу, піднесення його думок, утворення звичаїв, взагалі була керівницею життя народу. Віра давала найбагатший зміст, найбільше натхнення, найвищі ідеали всім передовим силам людства - філософам, поетам, мистцям, вченим; віра збуджувала й підносила людську думку, спонукала людність до того, чи іншого вирішення питань життя власного й світового»13.

В. Липківський наголошував, що віра $є$ прагненням людини до високого, безмежного, невідомого, до того, чого не може сягнути розум. На його погляд, людина замислювалася над різними питаннями і це сприяло розвиткові людської думки, науки. Греко-римська освіта, на його переконання, уся пройнята духом віри. Віра є природною властивістю усіх людей - «віра, як внутрішня сила душі $\epsilon$ безумовно світлом, завжди була в житті народів найбільш загальним світлом і наймогутнішою силою до поступу життя, до невпинного прогресу, цебто силою просвіщення». Навіть іслам давав найкращі зразки математичних знань у період свого піднесення. В. Липківський впевнений, що ні освіти, ні сучасної культури не було б без християнської віри. Він запитував: «...який би був моральний стан людности без християнства?»14.

Владика продовжував: християнство не тільки впливало на розвиток наукових знань, покращення умов життя людини. Найголовніше - християнська віра сприяла розкріпаченню душі людини, викликала радість і спокій.

На закиди, що християнство - то є опіум для народу, що не дозволяє боротися за матеріальне краще життя, В. Липківський несподівано відповідав: «Христова віра $\epsilon$ опіюм в його найкращому духовному розумінні, що дає найвищі і найчистіші радощі життя, підтримує людину в найтяжчих пригодах надією на Боже милосердя, дає їй силу добродушно зносити і злидні і хвороби і людську ворожість, все перемагати любов’ю, терпінням, надією на Бога. ...віра Христова, що вона вносить проміння світла в найтяжчу темряву життя. А от ті “специ” до полекшення життя, що їх дають безвірники: непримирима ворожість, безжалісність, безоглядне нищення тих, що ніби перешкоджають їх матеріяльному добробутові - от це є отрута, що губить життя, веде його до загину, це є справжня і вічна темрява»15.

Радянська влада у своїй антирелігійній пропаганді намагалася зробити акцент на тому, що релігія нічого немає спільного з робітничим класом. Навпаки, церковники обманюють простих людей. Ця теза пройшла червоною ниткою через усі антирелігійні брошури, статті у газетах. В. Липківський у проповіді спробував надати відповідь на ці закиди. Він переконував, що Ісус Христос після свого хрещення розпочав служіння не з Єрусалиму, а пішов в Галілею до рибалок, і показав, що його вчення найбільш близьке «до душі простого люду, трудящого народу, (якого тепер звичайно називають “пролетарями”)» ${ }^{16}$. Митрополит переконував, що Христове вчення, як

\footnotetext{
12 Христова віра є просвіщення, а не затьмарення Людини (Неділя перед Водохрещам) // Митрополит Василь Липківський. Проповіді на неділі й свята. Слово Христове до українського народу. URL: lypkivskyivasyl.in.ua/propovidi/006-prosvisch.html

13 Ibidem.

14 Ibidem.

15 Ibidem.

16 Люди, що сиділи в темряві, побачили світло велике (Неділя по Водохрещі) // Митрополит Василь Липківський. Проповіді на неділі й свята. Слово Христове до українського народу. URL: ypkivskyivasyl.in.ua/propovidi/013-svitlo.html
} 
тоді для вчених поган, так і сьогодні і для сучасних йому професорів - здається дуже простим. Людська наука, на його думку, є доступною лише для одиниць, а вчення Ісуса Христа - для усього народу.

Владика продовжував, що безвірники дорікають, що календар святих містить перелік духовних осіб, які займали вищі церковні посади, і жодного простого віруючого. Він доводив, що у календарі $є$ тільки незначна частина всіх святих, що залишили по собі помітний для людей внесок, через те, що займали вищі посади у церкві. Але більшість святих відома тільки Богові. 3 іронією В.Липківський нагадував своїм опонентам, що лідери більшовицького руху теж не із робітників вийшли: «Та й пролетарське небо - з кого складається? Маркс, Енгельс, Лібкнехт, Цеткин і інші найбільше відомі діячі з цього неба до пролетаріяту навіть не належали, а лише працювали на його утворення, а безліч звичайних пролетарів, може ще більш щирих, ніж їхні верхи, так і залишаються і залишаться нікому не відомими»17.

Проповіді дають підстави говорити, що духовенство не просто констатувало наявність антирелігійної боротьби, а й осмислювало їі перебіг. Зокрема, владика звернув увагу, що влада відмовилася від проведення брутальних, образливих карнавалів, гуртків безвірників на користь поширення природознавчих знань з метою заперечення існування Бога.

У 1920 -х рр. прокотилася хвиля есхатологічних рухів. В. Липківський розмірковував над причинами того, що змушувало тисячі віруючих йти із всенародними молитвами до «Калинівського чуда». На його думку, це було виявлення протесту проти образи християнської віри.

Митрополит на церковні гоніння запропонував мирні методи боротьби відповідно до Божих заповідей: перемагати «терпінням, стражданням, самовідданням себе на Христову працю, як і Христос віддав себе на страждання за нас»18.

Органічніше тема духовної протидії «богоборству» реалізується у виголошеній проповіді «Богоборство і боротьба за Церкву (На 5-ту Неділю Великого посту)». В. Липківський наголошував, що сьогодні часи запеклої найганебнішої боротьби 3 церквою. Як колись знущалися та насміхалися над Христом, так і сьогодні на антирелігійних виставах, лекціях, всенародних процесіях, карнавалах здійснюються найогидніші знущання над вченням Ісуса Христа. Владика пояснював, що безперечно для християн це $є$ огидним, але «знущання над Богом з боку людей це $\epsilon$ найбільше знущання їх над самими собою, а для Христа ці знущання і навіть смерть на хресті, це $є$ вславлення, і коли люди найгірше кепкують у свому богоборстві, тоді найголосніше лунає слово Христове: “Нині прославився Син Чоловічеський і Бог прославився в Ньому"»19.

У періодичних виданнях та антирелігійних брошурах влада навішувала на представників духовенства різні ярлики. Газета «Вісті Всеукраїнського Центрального Виконавчого Комітету Рад робітничих, селянських і червоноармійських депутатів» у

\footnotetext{
17 Хто $\epsilon$ «всі святі»? Про календар і святих, що з простого стану і українського народу (Неділя Всіх Святих) // Митрополит Василь Липківський. Проповіді на неділі й свята. Слово Христове до українського народу. URL: lypkivskyivasyl.in.ua/propovidi/109-vsi.html

18 Для чого св. Церква виносить нам сьогодні на поклоніння чесний Хрест Христовий? (На 3-тю Неділю посту) // Митрополит Василь Липківський. Проповіді на неділі й свята. Слово Христове до українського народу. URL: lypkivskyivasyl.in.ua/propovidi/059-hrest.html

19 Богоборство і боротьба за Церкву (На 5-ту Неділю Великого посту) // Митрополит Василь Липківський. Проповіді на неділі й свята. Слово Христове до українського народу. URL: lypkivskyivasyl.in.ua/propovidi/072-bogoborstvo.html
} 
випуску від 25 серпня 1921 р. опублікувала на першій сторінці статтю із промовистою назвою «Куркуляча церква» 20 . У публікації на всю країну доводилося, що «молоденька середня буржуазія українська» надумалася використати церкву для організації національної боротьби, що “"українізація” церкви - це простий перехід влади в церкві з рук поміщиків до рук куркулів і міщан»21.

У подальшому Українська автокефальна православна церква називалася «петлюрівською» та вважалася пристанищем діячів Української революції. Пропаганда мала систематичний і масштабний характер протягом 1920-1930-х рр. Промовистими $\epsilon$ вже самі заголовки розділів книжки «Українська автокефальна церква і Союз визволення України», одного з відомих організаторів Спілки войовничих безвірників, Д. Ігнатюка: «Церква - ворог нашого будівництва», «Як виникла автокефалія», «Під керівництвом БУД - СВУ», «Як вони працювали», «Розпалювання шовінізму», «Зв’язки з закордонною білогвардійщиною», «3 кого складалися автокефальні кадри». Автор виніс вирок: «...автокефальна церква після провалу Центральної Ради, Директорії та повстанства була створена й існувала на те, щоб виконувати роллю знаряддя в руках української буржуазії, закордонного фашизму та імперіалізму для боротьби проти радянської влади»22.

Владика не міг не оминути цієї теми у проповідях. Він заявив, що це безглуздий і чорний наклеп, і що ніякої політики церква не проводила. I що політичні ідеали мінливі і не можна до них прив'язуватися 23.

Ще однією суттєвою проблемою для церкви наприкінці 1920-х - протягом 1930-х рр. стало зречення сану духовенством. Митрополит засуджує це явище. Закликає не шукати десь істину, а звернутися до Ісуса Христа, як до єдиного шляху. Владика, утішаючи, із сумом наголошував, що якщо навіть серед учнів Ісуса Христа знайшовся зрадник, то не дивно, що серед служителів церкви є такі, що зраджують Ісуса Христа за сучасні срібняки, пишуть у часописах заяви про свій відхід від церкви ${ }^{24}$.

В. Липківський вважав, що з радянського богоборства необхідно винести уроки про оновлення форм церковного життя, щоб дати гідну відсіч антирелігійній політиці.

Владика сприймав нові духовні тенденції, якщо вони працювали на користь справі розвитку УАПЦ. У проповіді, присвяченій митрополиту П. Могилі, він пропонував «сміливо користуватись для життя й піднесення всіма кращими здобутками людства, навіть своїх ворогів, щоб їхньою зброєю їх же перемагати. Сам Петро Могила, хоч вперто боровся з католицтвом, але вільно перейняв від нього багато, що вважав корисним для життя Православної Церкви. А найбільше мусимо ми пильнувати того, щоб виховувати в собі і свому народі живий бадьорий дух релігійної й

\footnotetext{
20 Вісті ВУЦВК. 1921. 21 серпня.

21 Ibidem.

22 Ігнатюк Д. Українська автокефальна церква і Союз визволення України. Харків-Київ: Державне видавництво України, 1930. С. 23.

23 Урочистий в'їзд Христа в Єрусалим, як Творця нового релігійного життя та урочистий вхід нашої Церкви в життя нашого народу (Вербна Неділя) // Митрополит Василь Липківський. Проповіді на неділі й свята. Слово Христове до українського народу. URL: lypkivskyivasyl.in.ua/propovidi/078-vhid.html

24 Зрадник Христа - Юда, зрадництво рідному народові (На 2-гу Пасію) // Митрополит Василь Липківський. Проповіді на неділі й свята. Слово Христове до українського народу. URL: lypkivskyivasyl.in.ua/propovidi/052-juda.html
} 
національної свідомости, що єдиний тільки може перемогти всі бурі і хмари сучасного й майбутнього» 25.

Митрополит переймався питанням соборноправності - нагальною проблемою у житті українських церков. УАПЦ була провідником запровадження соборноправних принципів. У проповіді В.Липківський зауважував, що соборноправність церкви «обрізувалась» 3 давніх-давен і церковною, і державною владою. Єпископи забрали усе керівництво у церкві, зовсім «обрізавши» права мирян. Державна влада керувала проведенням соборів - «Царі зовсім обрізали навіть єпископські собори і вони мусіли припинитись»26. За весь час існування російської церкви під опікою царів, більш як 300 років, не було скликано жодного церковного Собору27.

Цікавим і промовистим $є$ використання у проповідях образів бандуристів, кобзарів як носіїв української традиції та культури. В. Липківському болить, що українська мова та традиції витіснялися із церкви: «Коли московська неволя вигнала з наших церков нашу рідну побожну пісню, нашу рідну мову, наші канти, де вони збереглися? Як до нас схоронилися? У лірників, у кобзарів, у жебраків на базарах. I коли величні представники в нас російської церкви і нації називають нашу мову, наші співи, канти - базарними, то це дійсно так. Лише на базарах у лірників збереглися, заховались до наших часів крихти з того величезного історичного скарбу, який уявляли собою українські давні народні оповідання, думи, канти, співи, і який так вперто намагались до щенту знищити наші російські керівники. Отже, величезне значення мають наші лірники, кобзарі і для нашої Матері України і зокрема для нашої церкви української. Їм наш народ найбільше мусить бути вдячний і за свою національну і за релігійну свідомість» 28 .

В. Липківського турбували переконання Російської православної церкви, консервативно налаштованих вірян у тому, що українська мова не гідна бути мовою служіння. На ці закиди Липківський відповідав, що «на всіх мовах Христос всі народи закликає до спасіння, для Нього всі мови однаково достойні»29.

Митрополит інтерпретував і таку ідею як «інтернаціоналізм». Його висловлювання дають нам зрозуміти, що владика відчував, що інтернаціоналізм замінявся великодержавницьким російським шовінізмом. Митрополит переконував, що національне об'єднання народів призведе до дійсного непохитного братерського єднання всіх народів. Справжнє інтернаціональне об'єднання, на його думку, це об’єднання народів в їх цілому національному єднанні, а не поодиноких людей, кла-

25 Спогад митрополита Петра Могили (Новий рік) // Митрополит Василь Липківський. Проповіді на неділі й свята. Слово Христове до українського народу. URL: lypkivskyivasyl.in.ua/propovidi/002-mohyla.html

${ }^{26}$ Новорічні думки й християнське розуміння обрізання (Новий рік) // Митрополит Василь Липківський. Проповіді на неділі й свята. Слово Христове до українського народу. URL: lypkivskyivasyl.in.ua/propovidi/003-nyth.html

27 Новорічні думки й християнське розуміння обрізання (Новий рік) // Митрополит Василь Липківський. Проповіді на неділі й свята. Слово Христове до українського народу. URL: lypkivskyivasyl.in.ua/propovidi/003-nyth.html

28 Христова освіта й сліпі бандуристи (Неділя 31-ша по Тройці) // Митрополит Василь Липківський. Проповіді на неділі й свята. Слово Христове до українського народу. URL: lypkivskyivasyl.in.ua/propovidi/018-osvita.html

${ }_{29}$ Син Чоловічеський прийшов, щоб знайти і спасти те, що загибає (Неділя 32-га по Тройці) // Митрополит Василь Липківський. Проповіді на неділі й свята. Слово Христове до українського народу. URL: lypkivskyivasyl.in.ua/propovidi/021-spasty.html 
сів чи партій ${ }^{30}$. Саме вільні народи повинні увійти до подібного союзу. Владика наводив історичні аргументи на підтвердження своїх думок, з посиланням на вірші Т. Шевченка.

Проповіді показують, що митрополит В.Липківський переймався не тільки рутинними питаннями, що постали перед віруючими в умовах антирелігійної політики. Владика замислювався над долею українського народу. Лунають не в одній проповіді такі філософські запитання, як: «Отже чи буде жити наш український народ?», «Що уявляють собою національні взаємовідносини поміж народами?», «А що уявляють собою взаємовідносини соціяльні поміж окремими клясами людства?»31.

Митрополит В. Липківський - український пророк, який передбачив суттєві проблеми людства та християнства у XX-XXI ст. - десакралізацію особистості, безцерковне та побутове православ'я. За допомогою рефлексії владика співвідносив християнські ідеали, національні цінності своєї церкви із більшовицькою ідеологією. На його переконання питання збереження християнської віри було поставлено найбільш гостро та принципово. Проповіді передають глибину стурбованості митрополита пропагандою матеріалізму, богоборчою політикою - викликами, які не тільки руйнували традиційний світогляд вірян, але й віщували фізичні страждання, втрату української ідентичності.

Поширенню ідей проти віри та церкви В.Липківський закликав протиставити справжнє християнське життя. А своїм служителям пропонував творити «рідну» для вірян церкву. Найчастіше у проповідях лунала тема страждань Ісуса Христа та віруючих. Репресивна політика влади по відношенню до духовенства змушувала говорити на подібні теми. Виконувати приписи Біблії аж до смерті - теза, яка пройшла скрізь усі проповіді. Хочеться підкреслити, що владика залишився вірним своєму Слову і в 1937 р. прийняв мученицьку смерть.

\section{REFERENCES}

Ihnatiuk, D. (1930). Ukrainska avtokefalna tserkva i Soiuz vyzvolennia Ukrainy [Ukrainian Autocephalous Church and Liberation Union of Ukraine]. Kharkiv; Kyiv: Derzhavne vydavnytstvo Ukrainy [in Ukrainian].

Lypkivskyi, Vasyl (n.d.). Propovidi na nedili i sviata. Slovo Khrystove do ukrainskoho narodu [Metropolitan Vasyl Lypkivsky. Sermons on Sundays and Holidays. The word of Christ to the Ukrainian people]. Retrieved from: http://lypkivskyivasyl.in.ua/propovidi/propovidi.html [in Ukrainian].

Polishchuk, V.T. (2013). Propovidi mytropolyta Vasylia Lypkivskoho: tiahlist tradytsii y novi aktsenty zhanru [The sermons of Metropolitan Vasily Lipkivsky: the gravity of tradition and new accents of the genre]. In Polishchuk V.T. (2013). Vybrane. T. 2: Rozstriliani talanty (Represovani pysmennyky Cherkashchyny). Cherkasy: Vydavets Yu.A. Chabanenko [in Ukrainian].

Prelovska, I.M. (2013). Dzherela z istorii Ukrainskoi Avtokefalnoi Pravoslavnoi Tserkvy (1921-1930) Ukrainskoi Pravoslavnoi Tserkvy (1930-1939) [Sources from the History of the Ukrainian Autocephalous Orthodox Church (1921-1930) - Ukrainian Orthodox Church (1930-1939)]. Kyiv: Instytut ukrainskoi arkheohrafii ta dzhereloznavstva imeni M.S. Hrushevskoto [in Ukrainian].

\footnotetext{
30 Хвилини перетворення життя нашого народу після «великої війни» (Неділя по Вознесінні) // Митрополит Василь Липківський. Проповіді на неділі й свята. Слово Христове до українського народу. URL: lypkivskyivasyl.in.ua/propovidi/102-peretv.html

31 Милосердя, як головний принцип життя людського (11-та Неділя по Тройці) // Митрополит Василь Липківський. Проповіді на неділі й свята. Слово Христове до українського народу. URL: lypkivskyivasyl.in.ua/propovidi/133-myloserdja; Життя Пресвятої Богородиці після смерти і Її піклування про наш нарід (На Першу Пречисту// Митрополит Василь Липківський. Проповіді на неділі й свята. Слово Христове до українського народу. URL: lypkivskyivasyl.in.ua/propovidi/135zhyttja.html
} 
Prelovska, I.M. (2014). Vidobrazhennia v homiletychnii spadshchyni mytropolyta UAPTs Vasylia Lypkivskoho yoho stavlennia do inshykh Tserkov (do 150-oi richnytsi (7/19 bereznia 1864 r. 27 lystopada 1937 r.) z dnia narodzhennia mytropolyta UAPTs Vasylia Lypkivskoho) [Reflection in the homiletic heritage of the Metropolitan of the UAOC Vasyl Lipkivsky his relation to other Churches (until the $150^{\text {th }}$ anniversary $(7 / 19$ March 1864 - November 27, 1937) from the birthday of the UAOC Metropolitan Vasyl Lipkivsky)]. Trudy Kyivskoi Dukhovnoi Akademii, 14, 241-251 [in Ukrainian].

\section{Tetiana Savchuk}

(Zaporizhzhya National University, Zaporizhzhya, Ukraine)

ORCID: https://orcid.org/0000-0002-1315-0513

\section{Metropolitan V. Lypkivskyi's Reflections on the Challenges of the Believers in Soviet Ukraine}

The reflections of the metropolitan of the Ukrainian Autocephalous Orthodox Church V. Lypkivskyi on the challenges of the Orthodox believers in the conditions of the anti-church policy of the authorities based on the materials of the sermons of the church hierarch are analyzed in the paper. We can see the reflections of erudite and courageous person - a connoisseur of the history of Ukrainian nation, church, philosophy, and the development of science. With the help of reflection, metropolitan V. Lypkivskyi correlated his personal views and values of his church with the propagated communist ideals. The church hierarch comprehended the past in order to develop life strategies for believers. To all the key events in the life of Jesus Christ, V. Lypkivskyi prepared sermons linked with the church's historical past and called for a renewal of the Christian life. The sermons promoted Christian doctrines, with particular emphasis on the benefits of just the Ukrainian Autocephalous Orthodox Church. It is noteworthy that in the sermons V. Lypkivskyi referred to the Holy Scripture and did not mention other ecclesiastical writings.

V. Lypkivskyi responded to the Communists' attempts to create society comprised only materialists. The church hierarch prophetically warned the believers who refused to attend church and denied God that they would receive nothing except a few ten-ruble notes and a piece of bread. The desacralization of life, according to the metropolitan, not only destroyed church institutions but also deprived a person of a sense of integrity, dignity of his or her personality. In fact, the metropolitan had a presentiment of the era of totalitarianism when the desacralization of the individual would occur. To counteract that, the hierarch tried to cultivate the personal faith of man in God. In his sermons, the idea of preserving the faith and counteracting the atheisation of the population raised most often. The texts of the sermons show that metropolitan V. Lypkivskyi paid attention not only to the routine issues urgent for believers in the context of anti-religious politics, but he thought about the fate of the whole Ukrainian nation. Metropolitan V. Lypkivskyi is a Ukrainian prophet who foresaw the essential problems of humanity and Christianity in the $20^{\text {th }}-21^{\text {st }}$ century - desacralization of personality, churchless and everyday life Orthodoxy.

Keywords: metropolitan V. Lypkivskyi, sermons, reflections, anti-church struggle, Soviet rule 